Giannoulis, K., Platis, I., Gougoulias, N., Wogiatzi, E. (2020): Influence of Trichoderma harzianum and Glomus mycorrhiza on biomass and essential oil yield of organic Ocimum basilicum cultivation. Agriculture and Forestry, 66 (3): 139-154

DOI: 10.17707/AgricultForest.66.3.12

Kyriakos GIANNOULIS ${ }^{1}$, Ilias PLATIS ${ }^{2}$,

Nikolaos GOUGOULIAS ${ }^{2}$, Eleni WOGIATZI ${ }^{2}$

\title{
INFLUENCE OF Trichoderma harzianum AND Glomus mycorrhiza ON BIOMASS AND ESSENTIAL OIL YIELD OF ORGANIC Ocimum basilicum CULTIVATION
}

\section{SUMMARY}

The growing interest in dealing with the cultivation of aromatic medicinal plants requires the study of factors related to the production process, which includes the development of plants in field, as well as their processing and the receipt of essential oils. The aim of this study was to investigate the effect of two organic formulations, Trichoderma harzianum (T22), and Glomus mycorrhiza (G), in the cultivation of seedlings of Ocimum basilicum variety "Genovese" fresh and dry weight, as well as essential oil content and its quality characteristics. For the purposes of the study a field experiment was conducted in 2018 and 2019, using a factorial experimental design, with two factors: a) control, b) Trichoderma harzianum (T22) and c) Mycorizas Glomus (G) under four replicates. There was found statistically significantly difference between the two harvests occurred in each year on fresh and dry weight while no significant difference was recorded through the tested treatments. Furthermore, there was recorded a decrease in the essential oil yield between the cultivating years (approximately 14\%), and also between annual cuts.

Finally, the most remarkable finding was that although the different treatments did not show significant differences in the quantitative characteristics of sweet basil in the case of quality characteristics with mycorrhiza treatments essential oil having 40 identified ingredients instead of 21 that identified in control. Therefore, the use of these organic formulations is suggested to be used only in case of essential oil production where a predetermined quality of essential oil will be known.

Keywords: aromatic-medicinal plants, Ocimum basilicum, organic plant production, yield, essential oil

\footnotetext{
${ }^{1}$ Giannoulis Kyriakos, (corresponding author: kyriakos.giannoulis@gmail.com), University of Thessaly, Dept of Agriculture, Crop Production and Rural Environment, Laboratory of Agronomy and Applied Crop Physiology, Fytokoy Str., 38446 Volos, GREECE.

${ }^{2}$ Platis Ilias, Gougoulias Nikolaos, Wogiatzi Eleni, University of Thessaly, Department of Agrotechnology, 41110, Larissa, GREECE.

Notes: The authors declare that they have no conflicts of interest. Authorship Form signed online.

Received:03/07/2020

Accepted:05/08/2020
} 


\section{INTRODUCTION}

Ocimum basilicum is a herbaceous plant of Lamiaceae family (Grayer et al., 1996) with annual and perennial species. It is one of the most popular aromatic plants and is widely used in cooking (Chalchat and Ozcan, 2008), pharmaceutical (Ahmed et al., 2014), confectionery and perfumery (Nguyen et al., 2010). Basil (Ocimum basilicum L.) in the science of medicine is called Herba Basilici and it is the most economically important species (Bravo et al., 2008).

It is considered to be native to the tropical and subtropical zones of Africa and Asia. It was firstly spread to India and other regions of Asia (Klimánková et al., 2008) and later on to Greece and the Mediterranean basin (Marotti et al. 1996; Sanda et al. 1998; Martins et al. 1999). It appeared in North America around 1620 through the first European settlers.

Ocimum genus includes more than 50 species. Ocimum basilicum is an economically and industrially important plant. It is a versatile plant with many different morphological characteristics, such as the size, the color and the texture of the leaves, the color of the inflorescence, but also the chemical composition of the essential oil. Basil has a smooth or slightly fluffy shoot, multi-branched with a height ranging up to $1 \mathrm{~m}$ (Blank et al., 2004). Its growth in width is almost the same as in height.

It is cultivated in areas with temperate climates, mild and short winters and cool summers. Basil requires high growth temperatures, with an excellent of $25^{\circ} \mathrm{C}$. At temperatures below $7^{\circ} \mathrm{C}$, especially in the early growing stages, the damage is irreversible. It is cultivated in rich and light soils, with a $\mathrm{pH}$ that can range from 4.5-8.2 (with an excellent value of 6.4), warmly sunny, irrigated and well drained. It has high water requirements, especially on hot summer days, but it needs attention to excessive watering.

Transplanting takes place in April-May at distances of 30-40 x 40-50 cm, by hand or with automatic transplanting machines in properly prepared soil. Before transplanting the plants are pruned at a height of $15 \mathrm{~cm}$ to encourage the growth of lateral branches. The broadleaf basil does not stop growing even at flowering stage.

The essential oil is stored in glandular trichomes of leaves (Sangwan et al., 2001) and it is used in fungicides or insecticides and in various pharmaceutical and industrial products (Grayer et al., 1996). The global production of basil essential oil varies from 50 to 100 tones (Lubbe and Verpoorte, 2011), while it is reported that Indian basil essential oil yield varies from 132.0 to $162.5 \mathrm{~kg} \mathrm{ha}^{-1}$ (Singh et al., 2010). Basil essential oil contains antifungal anti-bacterial properties and it is used as aromatic agents in food, perfumery and pharmaceutical industries (Varban et al., 2010; Wannissorn et al., 2005). The qualitative and quantitative improvement of essential oil production represents an area of high commercial interest (Copetta et al., 2006).

Nowadays, there is a high interest for organic products. In literature is reported investigation on different bio-fertilizers and/or symbiosis with fungi (Augé, 2001; Xavier and Boyetchko, 2002; Lee et al., 2013; Bharti et al., 2016) in 
case to increase the quantitative and qualitative characteristics of the yield, especially in the case of aromatic and pharmaceutical plants. The main goal of the studies that examine mycorrhizal colonization is to improve plants production (Sun et al., 2017; Gheisari et al., 2017). There are also few studies where is tested the symbiosis of arbuscular mycorrhiza and basil under water stress (Copetta et al., 2006; Hazzoumi et al., 2017).

Nowadays there is an increasing interest in cultivating basil in Greece and in Mediterranean basin in general, under organic production system. There has been created intense concern for the investigation of factors that can increase basil quantitative and qualitative characteristics. The aim of this study is to investigate the effect of two biological preparations, Trichoderma harzianum (T 22), and Glomus mycorrhiza (G) on Ocimum basilicum variety Genovese yield and essential oil.

\section{MATERIALS AND METHODS}

A field experiment was established on 2018 and 2019 at the Experimental Farm of the General Department of the University of Thessaly (Larissa plain, $\left.39^{\circ} 62^{\prime} 69^{\prime \prime} \mathrm{N}, 22^{\circ} 38^{\prime} 14^{\prime \prime} \mathrm{E}\right)$. Basil seedlings of the most cultivated variety Genovese were transplanted on 12/05/2019 and 13/05/2019 in a row distance of $40 \mathrm{~cm}$ and plant distance $20 \mathrm{~cm}$. The initial height of the established plants (seedlings) was $5 \mathrm{~cm}$. There was used a complete randomized experimental designs with three factors and four replicates. The tested factors were: i) control, ii) Trichoderma harzianum (T22), and iii) Glomus mycorrhiza (G). The applications of Trichoderma harzianum and Glomus mycorrhizae were performed during the transplanting stage applying 5ml/plant and 5gr/plant of T22 and G, respectively. There was installed a drip irrigation system with self-adjusting drippers of two-liter per hour in a distance of $60 \mathrm{~cm}$. Irrigation was carried out every seven days and lasting four hours at a time. There was not used any fertilization while the weed management took pat manually in both years.

Table 1. Physicochemical soil properties.

\begin{tabular}{|c|c|}
\hline Characteristics & $\begin{array}{c}\text { Depth } \\
0-30 \mathrm{~cm}\end{array}$ \\
\hline $\mathrm{pH}$ & 7.75 \\
\hline Organic matter $(\%)$ & 1.17 \\
\hline Electrical conductivity $(\mathrm{mS} / \mathrm{cm})$ & 0.08 \\
\hline CEC $(\mathrm{cmol} / \mathrm{kg})$ & 16.7 \\
\hline P-Olsen $(\mathrm{ppm})$ & 9.6 \\
\hline N-inorganic $(\mathrm{ppm})$ & 112 \\
\hline K-exchangeable $(\mathrm{ppm})$ & 214 \\
\hline Na-exchangeable $(\mathrm{ppm})$ & 71 \\
\hline
\end{tabular}


Before seedling establishment on 2018 a soil sampling up to a depth of 30 $\mathrm{cm}$ for further analysis carried out and the soil physicochemical characteristics are presented in Table 1.

Sampling carried out with two cuts on 06/07/20018 and on 05/09/2018 for the first experimental year and on 04/07/2019 and on 04/09/2019 for the second. Sampling took place at flowering stage and the plants were cut $4 \mathrm{~cm}$ above ground. In order to avoid any border effect, samplings were done from the $1 \mathrm{~m}^{2}$ of the inner rows of the plot of each replication. The plot size was $20 \mathrm{~m} 2$ (4 m width $\times 5$ m length). The fresh weight was measured at the field and then the samples were transported to the laboratory for air drying and further analysis.

Twelve and a half grammars of basil dry leaves were subjected to $250 \mathrm{ml}$ of water in a Clevenger-type distillation apparatus in case to determine the essential oil content. The hydro distillation lasted 105 minutes. The procedure was repeated three times for each sample and the essential oil content was estimated on the basis of DW plant material $\left(\mathrm{ml} 100 \mathrm{~g} \mathrm{~g}^{-1}\right)$. A further analysis of the distilled essential oil analysis was done using a GC-MS on a fused silica DB5 column and a Gas chromatograph interfaced with a mass spectrometer. The relative content of each compound was calculated as a percentage (\%) of the total chromatographic area and the results are expressed as the mean percentage (\%) of three replicates (Sarrou et al., 2017; Tsivelika et al., 2018).

The climatic data were recorded by an automatic meteorological station that was located near the experimental field. Finally all data were analyzed using GenStat ( $7^{\text {th }}$ Edition) package and the $\mathrm{LSD}_{.05}$ was used as the test criterion for assessing differences between means (Steel and Torrie, 1982).

\section{Weather conditions}

\section{RESULTS AND DISCUSSION}

The study area is characterized by a typical Mediterranean climate with cold humid winters and hot-dry summers.

\section{Weather data}

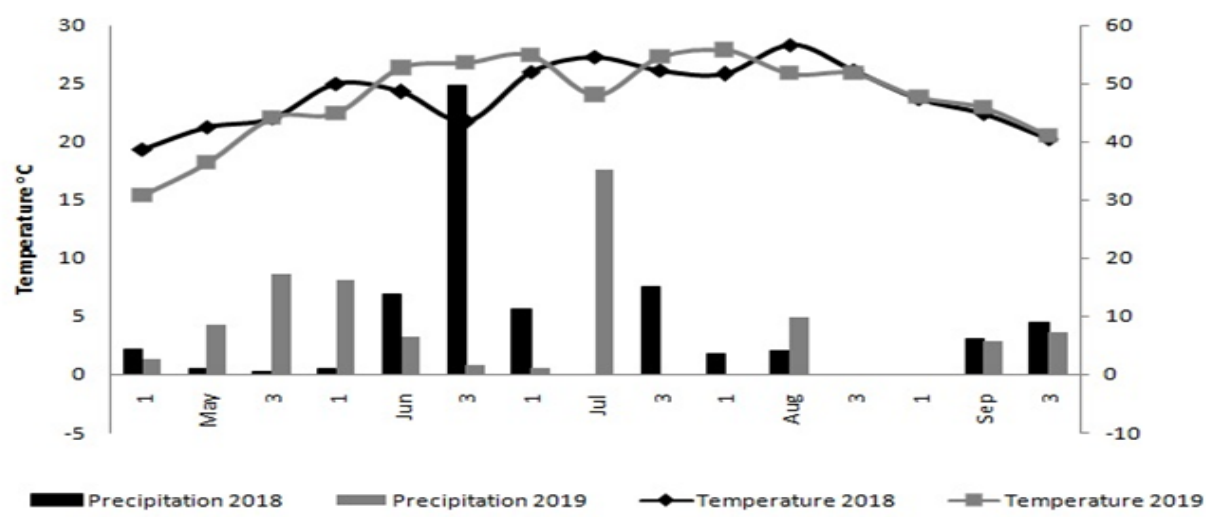

Figure 1. Average temperature and precipitation occurred in the study site during the growing periods of Ocimum basilicum (2018 and 2019). 
In particular, the average air temperature ranged during the transplanting period (May) was about 20.9 and $18.5^{\circ} \mathrm{C}$ on 2018 and 2019 , respectively, while during summer months (June-August) the average air temperature was about 26 for both years (Fig. 1). Precipitation during May was only $5.7 \mathrm{~mm}$ on 2018 and $28.5 \mathrm{~mm}$ on 2018, while during the summer months (June-August) was $98 \mathrm{~mm}$ and $70 \mathrm{~mm}$ on 2018 and 2019, respectively (Fig. 1).

\section{Basil fresh and dry yield}

The fact that the time intervals between the transplanting of the plants and the first cut, as well as between the first and second cut are the same and equal to two months in 2018 and 2019, and there was not observed extremely differences to the weather data, make the results comparable.

Table 2. Trichoderma and mycorrhiza application effect on basil fresh weight.

\begin{tabular}{|c|c|c|c|}
\hline \multirow{2}{*}{ Treatments } & Total Weight & Leaves Weight & Stems Weight \\
\hline & \multicolumn{3}{|c|}{$\mathrm{t} \mathrm{ha}^{-1}$} \\
\hline $\mathrm{T} 22$ & 14.52 & 8.91 & 5.61 \\
\hline G & 14.19 & 8.49 & 5.69 \\
\hline Control & 14.13 & 8.67 & 5.46 \\
\hline$L S D_{0.05}$ & ns & ns & ns \\
\hline 2018 & 16.71 & 10.27 & 6.44 \\
\hline 2019 & 11.84 & 7.11 & 4.74 \\
\hline$L S D_{0.05}$ & 0.701 & 0.501 & 0.325 \\
\hline $1^{\text {st }} \mathrm{Cut}$ & 16.61 & 10.66 & 5.95 \\
\hline $2^{\text {nd }} \mathrm{Cut}$ & 11.95 & 6.72 & 5.23 \\
\hline$L S D_{0.05}$ & 1.114 & 0.755 & 0.441 \\
\hline T22 x 2018 & 16.67 & 10.34 & 6.33 \\
\hline T22 x 2019 & 12.38 & 7.48 & 4.90 \\
\hline G x 2018 & 16.57 & 10.04 & 6.53 \\
\hline G x 2019 & 11.80 & 6.95 & 4.85 \\
\hline Control x 2018 & 16.91 & 10.45 & 6.46 \\
\hline Control x 2019 & 11.35 & 6.89 & 4.46 \\
\hline$L S D_{0.05}$ & ns & ns & ns \\
\hline
\end{tabular}




\begin{tabular}{|c|c|c|c|}
\hline $\mathrm{T} 22 \times 1^{\text {st }} \mathrm{Cut}$ & 16.42 & 10.55 & 5.87 \\
\hline $\mathrm{T} 22 \times 2^{\text {nd }} \mathrm{Cut}$ & 12.63 & 7.27 & 5.36 \\
\hline $\mathrm{G} \times 1^{\text {st }} \mathrm{Cut}$ & 16.56 & 10.53 & 6.03 \\
\hline $\mathrm{G} \times 2^{\text {nd }} \mathrm{Cut}$ & 11.81 & 6.46 & 5.35 \\
\hline Control x $1^{\text {st }} \mathrm{Cut}$ & 16.85 & 10.90 & 5.95 \\
\hline Control $\times 2^{\text {nd }} \mathrm{Cut}$ & 11.41 & 6.44 & 4.97 \\
\hline$L S D_{0.05}$ & ns & ns & ns \\
\hline $2018 \times 1^{\text {st }} \mathrm{Cut}$ & 20.94 & 13.49 & 7.45 \\
\hline $2019 \times 2^{\text {nd }}$ Cut & 12.49 & 7.06 & 5.43 \\
\hline $2018 \times 1^{\text {st }} \mathrm{Cut}$ & 12.28 & 7.83 & 4.45 \\
\hline $2019 \times 2^{\text {nd }}$ Cut & 11.41 & 6.38 & 5.02 \\
\hline$L S D_{0.05}$ & 1.261 & 0.867 & 0.522 \\
\hline $\mathrm{T} 22 \times 2018 \times 1^{\text {st }} \mathrm{Cut}$ & 20.26 & 13.05 & 7.21 \\
\hline $\mathrm{T} 22 \times 2018 \times 2^{\text {nd }} \mathrm{Cut}$ & 13.09 & 7.63 & 5.45 \\
\hline $\mathrm{T} 22 \times 2019 \times 1^{\text {st }} \mathrm{Cut}$ & 12.58 & 8.06 & 4.52 \\
\hline $\mathrm{T} 22 \times 2019 \times 2^{\text {nd }}$ Cut & 12.17 & 6.90 & 5.27 \\
\hline $\mathrm{G} \times 2018 \times 1^{\text {st }} \mathrm{Cut}$ & 20.78 & 13.35 & 7.43 \\
\hline $\mathrm{G} \times 2018 \times 2^{\text {nd }} \mathrm{Cut}$ & 12.35 & 6.72 & 5.63 \\
\hline $\mathrm{G} \times 2019 \times 1^{\text {st }} \mathrm{Cut}$ & 12.34 & 7.71 & 4.64 \\
\hline $\mathrm{G} \times 2019 \times 2^{\text {nd }} \mathrm{Cut}$ & 11.27 & 6.20 & 5.07 \\
\hline Control $\mathrm{x} 2018 \times 1^{\text {st }} \mathrm{Cut}$ & 21.77 & 14.07 & 7.70 \\
\hline Control $\times 2018 \times 2^{\text {nd }}$ Cut & 12.04 & 6.82 & 5.22 \\
\hline Control x $2019 \times 1^{\text {st }} \mathrm{Cut}$ & 11.92 & 7.73 & 4.19 \\
\hline Control $\times 2019 \times 2^{\text {nd }}$ Cut & 10.78 & 6.05 & 4.73 \\
\hline$L S D_{0.05}$ & ns & ns & ns \\
\hline $\mathrm{CV}(\%)$ & 12.9 & 14.3 & 13.0 \\
\hline
\end{tabular}

The total fresh and/or dry weight did not statistical differ for the tested treatments in both cultivating years (Table 2 and Table 3 ). The only statistical significant differences that were found are between the cultivating years and the different cuts in the same year. There was observed a reduction in the fresh weight during the second experimentation year and between the first and second cut for both years, at rates of $30 \%$ and $28 \%$ respectively. These reductions were not statistically significant. The reduction in the fresh weight observed between the cuttings (1st and 2nd) during the second year (2019) was considered to be 
lower. Finally, it was found that leaves fresh and dry weight was higher comparing to stems weight for both years (Table 2).

In many studies has been shown that by increasing the available nitrogen significantly increases the fresh weight of plants, up to an excellent one (Anwar et al., 2005a; Sifola and Barbieri, 2006; Giannoulis et al., 2020), which was not found in the current study although it could be expect that this would happen due to the use of Trichoderma and Mycorrhiza that contribute to a better nutrient uptake from the soil. Almost the same results were reported by Kandil et al., (2009) who found that the fresh weight of basil Genovese variety had no significant differences among fertilized plots with 25, 50, 75 and 100\% from recommended doses of N-P-K.

As it has been reported the yield of 2018 was higher compared with the produced yield in 2019 reaching an average yield of $16.7 \mathrm{t} \mathrm{ha}^{-1}$ in total of which $10.3 \mathrm{t} \mathrm{ha}^{-1}$ were the fresh leaves (Table 2). The contained moisture was for all parts the same $84 \%$.

Table 3. Trichoderma and mycorrhiza application effect on basil dry weight.

\begin{tabular}{|c|c|c|c|}
\hline \multirow{2}{*}{ Treatments } & Total Weight & Leaves Weight & Stems Weight \\
\cline { 2 - 4 } & \multicolumn{3}{|c|}{$\mathrm{t} \mathrm{ha}^{-1}$} \\
\hline $\mathrm{T} 22$ & 2.63 & 1.62 & 1.01 \\
\hline $\mathrm{G}$ & 2.54 & 1.52 & 1.02 \\
\hline Control & 2.80 & 1.72 & 1.08 \\
\hline$L S D_{0.05}$ & $\mathrm{~ns}$ & $\mathrm{~ns}$ & $\mathrm{~ns}$ \\
\hline 2018 & 2.68 & 1.65 & 1.04 \\
\hline 2019 & 2.63 & 1.59 & 1.07 \\
\hline$L S D_{0.05}$ & $\mathrm{~ns}$ & $\mathrm{~ns}$ & $\mathrm{~ns}$ \\
\hline $1^{\text {st }} \mathrm{Cut}$ & 3.16 & 2.03 & 1.13 \\
\hline $2^{\text {nd }} \mathrm{Cut}$ & 2.15 & 1.21 & 0.94 \\
\hline$L S D_{0.05}$ & 0.225 & 0.151 & 0.086 \\
\hline $\mathrm{T} 22 \times 2018$ & 2.65 & 1.64 & 1.00 \\
\hline $\mathrm{T} 22 \times 2019$ & 2.62 & 1.59 & 1.02 \\
\hline $\mathrm{G} \times 2018$ & 2.54 & 1.54 & 1.00 \\
\hline $\mathrm{G} \times 2019$ & 2.54 & 1.51 & 1.03 \\
\hline Control $\times 2018$ & 2.86 & 1.76 & 1.10 \\
\hline
\end{tabular}




\begin{tabular}{|c|c|c|c|}
\hline Control x 2019 & 2.73 & 1.67 & 1.06 \\
\hline$L S D_{0.05}$ & ns & ns & ns \\
\hline $\mathrm{T} 22 \times 1^{\text {st }} \mathrm{Cut}$ & 3.06 & 1.97 & 1.09 \\
\hline $\mathrm{T} 22 \times 2^{\text {nd }} \mathrm{Cut}$ & 2.20 & 1.27 & 0.93 \\
\hline $\mathrm{G} \times 1^{\text {st }} \mathrm{Cut}$ & 3.08 & 1.95 & 1.13 \\
\hline $\mathrm{G} \times 2^{\text {nd }} \mathrm{Cut}$ & 2.00 & 1.09 & 0.90 \\
\hline Control x $1^{\text {st }}$ Cut & 3.37 & 216.0 & 1.18 \\
\hline Control $\times 2^{\text {nd }} \mathrm{Cut}$ & 2.25 & 1.27 & 0.98 \\
\hline$L S D_{0.05}$ & ns & ns & ns \\
\hline $2018 \times 1^{\text {st }} \mathrm{Cut}$ & 3.27 & 2.11 & 1.16 \\
\hline $2019 \times 2^{\text {nd }}$ Cut & 2.09 & 1.19 & 0.91 \\
\hline $2018 \times 1^{\text {st }} \mathrm{Cut}$ & 3.05 & 1.95 & 1.10 \\
\hline $2019 \times 2^{\text {nd }}$ Cut & 2.21 & 1.24 & 0.97 \\
\hline$L S D_{0.05}$ & ns & ns & ns \\
\hline T22 x $2018 \times 1^{\text {st }}$ Cut & 3.18 & 2.05 & 1.13 \\
\hline $\mathrm{T} 22 \times 2018 \times 2^{\text {nd }} \mathrm{Cut}$ & 2.11 & 1.23 & 0.88 \\
\hline $\mathrm{T} 22 \times 2019 \times 1^{\text {st }} \mathrm{Cut}$ & 2.95 & 1.89 & 1.06 \\
\hline $\mathrm{T} 22 \times 2019 \times 2^{\text {nd }}$ Cut & 2.29 & 1.30 & 0.99 \\
\hline $\mathrm{G} \times 2018 \times 1^{\text {st }} \mathrm{Cut}$ & 3.21 & 2.06 & 1.15 \\
\hline $\mathrm{G} \times 2018 \times 2^{\text {nd }} \mathrm{Cut}$ & 1.87 & 1.02 & 0.85 \\
\hline $\mathrm{G} \times 2019 \times 1^{\text {st }} \mathrm{Cut}$ & 2.95 & 1.84 & 1.11 \\
\hline $\mathrm{G} \times 2019 \times 2^{\text {nd }} \mathrm{Cut}$ & 2.13 & 1.17 & 0.95 \\
\hline Control x $2018 \times 1^{\text {st }}$ Cut & 3.43 & 2.22 & 1.21 \\
\hline Control $\times 2018 \times 2^{\text {nd }} \mathrm{Cut}$ & 2.30 & 1.31 & 0.99 \\
\hline Control x $2019 \times 1^{\text {st }} \mathrm{Cut}$ & 3.24 & 2.10 & 1.14 \\
\hline Control x $2019 \times 2^{\text {nd }}$ Cut & 2.21 & 1.24 & 0.97 \\
\hline$L S D_{0.05}$ & ns & ns & ns \\
\hline $\mathrm{CV}(\%)$ & 14.0 & 15.4 & 13.7 \\
\hline
\end{tabular}

The dry herbage yield reported in previous studies where different sweet basil genotypes were tested varied from 0.6 to $6.2 \mathrm{t} \mathrm{ha}^{-1}$ yield (Bowes and Zheljazkov, 2004; Anwar et al., 2005b; Zheljazkov et al., 2008b; Zheljazkov et 
al., 2008a). The above variation reflects the different genetically, agronomical and environmental effects and is within the yield variations reported in this study.

\section{Essential oil yield}

The most important quality criterion of aromatic-medicinal plants is essential oil. The essential oil content was found to have a statistically significant higher content for the harvested yield in 2018 compared to the one measured in 2019 (0.47 and $0.43 \%$ respectively, Table 4$)$ and also between the two cuts in each $\left(0.8\right.$ and $0.1 \%$ in the $1^{\text {st }}$ and the $2^{\text {nd }}$ cut, respectively; Table 4$)$. There was not found any statistically significant difference between the treatments or the interactions with the cuts and the growing year (Table 4).

Table 4. Trichoderma and mycorrhiza application effect on basil essential oil content and yield.

\begin{tabular}{|c|c|c|}
\hline \multirow{2}{*}{ Treatments } & Essential oil Content & Essential Oil Yield \\
\hline & $\%$ & $\mathrm{~kg} \mathrm{ha}^{-1}$ \\
\hline $\mathrm{T} 22$ & 0.44 & 8.34 \\
\hline G & 0.49 & 8.28 \\
\hline Control & 0.46 & 9.54 \\
\hline$L S D_{0.05}$ & ns & ns \\
\hline 2018 & 0.47 & 9.36 \\
\hline 2019 & 0.43 & 8.08 \\
\hline$L S D_{0.05}$ & 0.037 & 0.814 \\
\hline $1^{\text {st }} \mathrm{Cut}$ & 0.80 & 16.21 \\
\hline $2^{\text {nd }} \mathrm{Cut}$ & 0.10 & 1.24 \\
\hline$L S D_{0.05}$ & 0.030 & 0.900 \\
\hline $\mathrm{T} 22 \times 2018$ & 0.47 & 9.07 \\
\hline T22 x 2019 & 0.41 & 7.61 \\
\hline G x 2018 & 0.47 & 9.01 \\
\hline G x 2019 & 0.43 & 7.55 \\
\hline Control x 2018 & 0.47 & 10.01 \\
\hline Control x 2019 & 0.45 & 9.08 \\
\hline$L S D_{0.05}$ & ns & $\mathrm{ns}$ \\
\hline
\end{tabular}




\begin{tabular}{|c|c|c|}
\hline $\mathrm{T} 22 \times 1^{\text {st }}$ Cut & 0.77 & 15.51 \\
\hline $\mathrm{T} 22 \times 2^{\text {nd }} \mathrm{Cut}$ & 0.09 & 1.17 \\
\hline $\mathrm{G} \times 1^{\text {st }} \mathrm{Cut}$ & 0.79 & 15.33 \\
\hline $\mathrm{G} \times 2^{\text {nd }} \mathrm{Cut}$ & 0.11 & 1.23 \\
\hline Control x $1^{\text {st }} \mathrm{Cut}$ & 0.82 & 17.78 \\
\hline Control $x 2^{\text {nd }} \mathrm{Cut}$ & 0.10 & 1.31 \\
\hline$L S D_{0.05}$ & ns & ns \\
\hline $2018 \times 1^{\text {st }} \mathrm{Cut}$ & 0.83 & 17.41 \\
\hline $2019 \times 2^{\text {nd }} \mathrm{Cut}$ & 0.11 & 1.32 \\
\hline $2018 \times 1^{\text {st }} \mathrm{Cut}$ & 0.77 & 15.00 \\
\hline $2019 \times 2^{\text {nd }} \mathrm{Cut}$ & 0.09 & 1.16 \\
\hline$L S D_{0.05}$ & $\mathrm{~ns}$ & 1.15 \\
\hline $\mathrm{T} 22 \times 2018 \times 1^{\text {st }} \mathrm{Cut}$ & 0.82 & 16.78 \\
\hline $\mathrm{T} 22 \times 2018 \times 2^{\text {nd }} \mathrm{Cut}$ & 0.11 & 1.36 \\
\hline $\mathrm{T} 22 \times 2019 \times 11^{\text {st }} \mathrm{Cut}$ & 0.75 & 14.24 \\
\hline $\mathrm{T} 22 \times 2019 \times 2^{\text {nd }} \mathrm{Cut}$ & 0.08 & 0.97 \\
\hline Gx $2018 \times 1^{\text {st }}$ Cut & 0.82 & 16.84 \\
\hline G x $2018 \times 2^{\text {nd }}$ Cut & 0.12 & 1.18 \\
\hline Gx $2019 \times 11^{\text {st }}$ Cut & 0.75 & 13.82 \\
\hline G $\times 2019 \times 2^{\text {nd }}$ Cut & 0.11 & 1.28 \\
\hline Control x $2018 \times 1^{\text {st }} \mathrm{Cut}$ & 0.84 & 18.61 \\
\hline Control $\times 2018 \times 2^{\text {nd }} \mathrm{Cut}$ & 0.11 & 1.41 \\
\hline Control x $2019 \times 1^{\text {st }}$ Cut & 0.81 & 16.94 \\
\hline Control x $2019 \times 2^{\text {nd }}$ Cut & 0.10 & 1.21 \\
\hline$L S D_{0.05}$ & ns & ns \\
\hline CV (\%) & 11.1 & 17.0 \\
\hline
\end{tabular}

The lowest $(0.08 \%$ in 2019 during the second cut to the Trichoderma; Table 4 ) and the highest ( $0.84 \%$ in 2018 during the first cut to the control; Table 4) essential oil content was found in the case of Trichoderma and control, respectively. However, the most remarkable finding was that both Trichoderma and mycorrhiza had the same essential oil content in the first cut for both growing years.

Multiplying leaves dry yield per hectare with the essential oil content of each treatment, result to the essential oil yield per hectare. This yield is presented 
in Table 4 and shows that the yield of 2018 is statistically significantly higher compared to the yield of 2019 (9.36 and $8.08 \mathrm{~kg} \mathrm{ha}^{-1}$, respectively). This difference is much higher comparing the two cuts independently growing year with the second cut producing thirteen times less essential oil yield per hectare (Table 4).

The increased essential oil content during the summer months has been observed in numerous studies of many aromatic plants of the Lamiaceae family (Putievsky et al. 1986; Kokkini et al. 1997). It seems that the content of essential oils shows seasonal diversity, with a decrease in autumn and higher amounts in summer. The role of temperature and UVB radiation is very important (Fahlen et al. 1997; Ioannidis et al. 2002), as well as the light duration and intensity, which has an increasing effect on essential oil production (Yamaura et al. 1989). Thus the reason that the second cut in the study area had extremely lower essential oil content.

The range of the essential content of the current study was within the usual content reported in other studies where it is reported that the essential oil content of different sweet basil genotypes varying from $0.07 \%$ to $1.92 \%$ in dry herbage (Pino et al., 1994; Wetzeil et al., 2002; Bowes and Zheljazkov, 2004.; Anwar et al., 2005b, Zheljazkov et al., 2008a). The above essential oil content corresponds to a basil oil yield ranging between $3.1 \mathrm{~kg} \mathrm{ha}^{-1}$ and $58.8 \mathrm{~kg} \mathrm{ha}^{-1}$, a range that includes the essential oil yield of this study.

\section{Essential oil composition}

The essential oil analysis shown that in the produced essential oil were identified 40 ingredients (Table 5). The main ones recorded high concentrations (according to control treatments) are methyl chavicol (51.5\%), cadinol (7.6\%), geranial (7.3\%), linalool (7.1\%), a-guaiene (4.4\%), c-cadiene $(2.7 \%)$ and cisCadina 1(6) - 4 diene (2.5\%).

The most remarkable finding was that although differential treatments did not show significant differences in the quantitative characteristics of sweet basil cultivation, in the case of quality characteristics this difference seems to be important. As it is presented in Table 5, there have been many differences between the treatments and the control in the contents of the individual ingredients. The ingredients that identified to the essential oil of the mycorrhiza treatments were 40 instead of 21 and 19 that identified in control and trichoderma, respectively.

The essential oil of the mycorrhiza treatments has more ingredients that even in small quantities make it richer. Furthermore, it must be emphasized that there was found also a high difference to the $\%$ content of the found compound (Table 5).

Previous studies have assessed the chemical composition of essential oils of $O$. basilicum presenting a high variability (Edris and Farrag, 2003; Rattanachaikunsopon and Phumkhachorn, 2010). 
Table 5. Essential oil compounds found to the tested treatments (average values for both.

\begin{tabular}{|c|c|c|c|}
\hline Ingredient (\%) & Control & Trichoderma & Mycorrhiza \\
\hline a-Pinene & 0 & 0 & 0.014 \\
\hline Camphlene & 0 & 0 & 0.004 \\
\hline Sabinene & 0 & 0 & 0.035 \\
\hline b-Pinene & 0 & 0 & 0.366 \\
\hline Mycerene & 0 & 0 & 0.065 \\
\hline Lauroene & 0.452 & 0.418 & 0.420 \\
\hline 1,8 Cineole & 0.765 & 0.712 & 0.701 \\
\hline Z-b Ocimene & 0 & 0 & 0.006 \\
\hline E-b- Ocimene & 0.616 & 0.583 & 0.534 \\
\hline C-Terpinene & 0 & 0 & 0.015 \\
\hline cis-Terpinene hydrate & 0 & 0 & 0.020 \\
\hline cis Linalool oxide & 0 & 0 & 0.027 \\
\hline Linalool & 7.083 & 7.209 & 6.696 \\
\hline 1-octen-3-yl acetate & 0 & 0 & 0.006 \\
\hline Menthone & 0 & 0 & 0.063 \\
\hline Borneol/isomethone & 0 & 0 & 0.296 \\
\hline Menthol & 0 & 0 & 0.029 \\
\hline Terpinen-4-ol & 0 & 0 & 0.058 \\
\hline a-Terpineol & 0 & 0 & 0.065 \\
\hline Methyl chavicol & 51.497 & 56.603 & 56.030 \\
\hline Geraniol & 0 & 0 & 0.804 \\
\hline Geranial & 7.280 & 2.888 & 2.089 \\
\hline Bornyl Acetate & 0 & 0 & 0.013 \\
\hline Methyl Acetate & 0.134 & 0 & 0.141 \\
\hline d-Elemene & 0.016 & 0 & 0.010 \\
\hline a-Cubanene & 0.096 & 0 & 0.035 \\
\hline a-Copaene & 1.257 & 1.344 & 1.071 \\
\hline b-Elemene & 0.123 & 0.147 & 0.149 \\
\hline a-Guaiene & 4.358 & 4.750 & 4.066 \\
\hline a-Humuulene & 3.076 & 2.677 & 2.365 \\
\hline cis-Cadina 1(6) - 4 diene & 2.508 & 3.469 & 2.350 \\
\hline b-Acoradiene & 0.735 & 0 & 0.522 \\
\hline c-Muurolene & 0.759 & 0.742 & 0.630 \\
\hline b-Selinere & 0.470 & 0.472 & 0.420 \\
\hline Aciphylene & 2.445 & 2.352 & 2.058 \\
\hline c-Bulnesene & 0.908 & 0.971 & 0.866 \\
\hline c-Cadiene & 2.733 & 2.674 & 2.632 \\
\hline Spathulenol & 0 & 1.054 & 1.149 \\
\hline 1,10 di-epi Cubenol & 0 & 0.986 & 0.903 \\
\hline Cadinol & 7.612 & 7.423 & 6.535 \\
\hline
\end{tabular}


According to the different genotype of $O$. basilicum, there were found different compounds content to linalool (Hussain et al., 2008; Pozzatti et al., 2008; Rao et al., 2011), eugenol (Nardoni et al., 2015), geraniol (Cardoso et al., 2016) and methyl chavicol (Opalchenova and Obreshkova, 2003).

Finally in previous studies was reported essential oil of $O$. basilicium with high amounts of methyl chavicol 45-86\% (Bozin et al., 2006; Hossain et al., 2010; Shirazi et al., 2014; Císarová et al., 2016; Avetisyan et al., 2017), which is in line with the findings of the current study.

\section{CONCLUSIONS}

This study was conducted during 2018 and 2019 seasons, at the General Department of the University of Thessaly, to study the effect of two biological preparations, Trichoderma harzianum (T 22), and Glomus mycorrhiza (G) on Ocimum basilicum variety Genovese yield and essential oil. The results indicated that the above treatments did not affect the quantitative characteristics but only the qualitative ones. Moreover, sweet basil yield was different between the cuts with the first one producing the major yield. Therefore, an overall conclusion could be that sweet basil could be a promising annual aromatic-medicinal crop and different essential oil quality could be produced depending on the use of or not of mycorrhiza or trichoderma according to market requirements for its use.

\section{ACKNOWLEDGMENTS}

This work was supported by the General Department, University of Thessaly, Greece.

\section{REFERENCES}

Ahmed EA, Hassan EA, Tobgy KM, Ramadan EM. 2014. Evaluation of rhizobacteria of some medicinal plants for plant growth promotion and biological control. Ann. Agric. Sci. 59(2):273-280.

Anwar F, Ashraf M, Bhanger MI. 2005a. Interprovenance variation in the composition of Moringa oleifera oil seeds from Pakistan. J Am. Oil Chem. Soc. 82:45-51.

Anwar M, Patra DD, Chand S, Kumar A, Naqvi AA, Khanuja SPS. 2005b. Effect of organic manures and inorganic fertilizer on growth, herb and oil yield, nutrient accumulation, and oil quality of French basil. Commun. Soil Sci. Plant Anal. $36: 1737-1746$.

Augé RM. 2001. Water relations, drought and vesicular-arbuscular mycorrhizal symbiosis. Mycorrhiza 11:3-42.

Avetisyan A, Markosian A, Petrosyan M, Sahakyan N, Babayan A, Aloyan S, Trchounian A, 2017. Chemical composition and some biological activities of the essential oils from basil Ocimum different cultivars. BMC Complement. Altern. Med. 17:60.

Bharti N, Barnawal D, Wasnik K, Tewari SK, Kalra A. 2016. Co-inoculation of Dietzia natronolimnaea and Glomus intraradices with vermicompost positively influences Ocimum basilicum L. growth and resident microbial community structure in salt affected low fertility soils. Appl. Soil Ecol. 100:211-225.

Blank AF, Carvalho Filho JLS, Santos Neto AL, Alves PB, Arrigoni-Blank MF, SilvaMann R, MendonćEa MC. 2004. Caracterizacão morfológica e agronômica de acessos de manjericão e alfavaca. Hortic. Bras. 22:113-116. 
Bowes K, Zheljazkov V.D. 2004. Ocimum sanctum L. and Ocimum basilicum L. grown in Nova Scotia, Canada show potential as essential oil crops. J. Amer. Soc. Hort. Sci. 129:789-794.

Bozin B, Mimca-Dukic N, Simin N, Anackov G. 2006. Characterization of the volatile composition of essential oils of some Lamiaceae spices and the antimicrobial and antioxidant activities of the entire oils. J. Agric. Food Chem. 54:1822-1828.

Bravo E, Amrani S, Aziz M, Harnafi H, Napolitano M. 2008. Ocimum basilicum ethanolic extract decreases cholesterol synthesis and lipid accumulatio in human macrophages. Fitoterapia 79:515-523.

Cardoso NNR, Alviano CS, Blank AF, Romanos MTV, Fonseca BB, Rozental S, Rodrigues IA, Alviano DS. 2016. Synergism effect of the essential oil from Ocimum basilicum var. Maria Bonita and its major components with fluconazole and its influence on ergosterol biosynthesis. Evid. Based. Complement. Alternat. Med. 2016:5647182.

Chalchat JC, Ozcan MM. 2008. Comparative essential oil composition of flowers, leaves and stems of basil (Ocimum basilicum L.) used as herb. Food Chem. 110:501-503.

Císarová M, Tančinová D, Medo J, Kačániová M. 2016. The in vitro effect of selected essential oils on the growth and mycotoxin production of Aspergillus species. J. Environ. Sci. Heal. Part B. 51:668-674.

Copetta A, Lingua G, Berta G. 2006. Effects of three AM fungi on growth, distribution of glandular hairs, and essential oil production in Ocimum basilicum L. var. Genovese. Mycorrhiza 16:485-494.

Edris AE, Farrag ES. 2003. Antifungal activity of peppermint and sweet basil essential oils and their major aroma constituents on some plant pathogenic fungi from the vapor phase. Nahrung-Food. 47:117-121.

Fahlen A, Welander M, Wennersten R. 1997. Effects of light-temperature regimes on plant growth and essential oil yield of selected aromatic plants. J. Sci. Food Agric. 73:111-119.

Gheisari S, Movahhedi M, Salehi A, Gholamhoseini M. 2017. Responses of field grown fennel (Foeniculum vulgare Mill.) to different mycorrhiza species under varying intensities of drought stress. J. Appl. Res. Med. Aromatic Plants, 5:16-25.

Giannoulis KD, Kamvoukou CA, Gougoulias N, Wogiatzi E. 2020. Irrigation and nitrogen application affect Greek oregano (Origanum vulgare ssp. hirtum) dry biomass, essential oil yield and composition. Ind. Crops Prod. 150:112392.

Grayer RG, Kite GC, Goldstone FJ, Bryan SE, Paton A, Putievsky E. 1996. Infraspecific taxonomy and essential oil chemotypes in basil, Ocimum basilicum. Phytochemistry 43:1033-1039.

Hazzoumi Z, Moustakime Y, Elharchli E, Joutei K. 2017. Effect of arbuscular mycorrhizal fungi (AMF) and water stress on growth, phenolic compounds, glandular hairs, and yield of essential oil in basil (Ocimum gratissimum L.). Chem. Biol. Technol. Agric. 2:10.

Hossain MA, Kabir MJ, Salehuddin SM, Rahman SMM, Das AK, Singha SK, Alam MK, Rahman A. 2010. Antibacterial properties of essential oils and methanol extracts of sweet basil Ocimum basilicum occurring in Bangladesh. Pharm. Biol. 48:504 511.

Hussain AI, Anwar F, Hussain Sherazi ST, Przybylski R. 2008. Chemical composition, antioxidant and antimicrobial activities of basil (Ocimum basilicum) essential oils depends on seasonal variations. Food Chem. 108:986-995. 
Ioannidis D, Bonner L, Johnson CB. 2002. UN-B is required for normal development of oil glands in Ocimum basilicum L. (sweet basil). Ann. Bot. 90:453-460.

Kandil MAM, Khatab ME, Ahmed SS, Schnug E. 2009. Herbal and essential oil yield of Genovese basil (Ocimum basilicum L.) grown with mineral and organic fertilizer sources in Egypt. Journal FüR Kulturpflanzen, 61(12):443-449.

Klimánková E, Holadová K, Hajšlová J, Cájka T, Poustka J, Koudela M. 2008. Aroma profiles of five basil (Ocimum basilicum L.) cultivars grown under conventional and organic conditions. Food Chem. 107:464-472.

Kokkini S, Karousou R, Dardioti A, Krigas N, Lanaras T. 1997. Autumn essential oils of Greek oregano. Phytochemistry, 44:883-886.

Lee EH, Eo JK, Ka KH, Eom AH. 2013. Diversity of arbuscular mycorrhizal fungi and their roles in ecosystems. Mycobiology 41(3):121-125.

Lubbe A, Verpoorte R. 2011. Cultivation of medicinal and aromatic plants for specialty industrial materials. Ind. Crops Prod. 34(10):785-801.

Marotti M, Piccaglia R, Giovanelli E. 1996. Differences in essential oil composition of basil (Ocimum basilicum L.) Italian cultivars related to morphological characteristics. J. Agr. Food Chem., 14:3926-3929.

Martins AP, Salgueiro LR, Vila R, Tomi F, Canigueral S, Casanova J, Proença da Cunha A, Adzet T. 1999. Composition of the essential oils of Ocimum canum, $O$. gratissimum and O. minimum. Planta Med. 65:187-189.

Nardoni S, Giovanelli S, Pistelli L, Mugnaini L, Profili G, Pisseri F, Mancianti F. 2015. In vitro activity of twenty commercially available, plant-derived essential oils against selected dermatophyte species. Nat. Prod. Commun. 10:1473-1478.

Nguyen PM, Kwee EM, Niemeyer ED. 2010. Potassium rate alters the antioxidant capacity and phenolic concentration of basil (Ocimum basilicum L.) leaves. Food Chem. 123:1235-1241.

Opalchenova G, Obreshkova D. 2003. Comparative studies on the activity of basil - an essential oil from Ocimum basilicum L. - against multidrug resistant clinical isolates of the genera Staphylococcus, Enterococcus and Pseudomonas by using different test methods. J. Microbiol. Methods 54:105-110.

Pino JA, Roncal E, Rosado A, Goire I. 1994. The essential oil of Ocimum basilicum L. from Cuba. J. Essent. Oil Res. 6:89-90.

Pozzatti P, Scheid LA, Spader TB, Atayde ML, Santurio JM, Alves SH. 2008. In vitro activity of essential oils extracted from plants used as spices against fluconazoleresistant and fluconazole-susceptible Candida spp. Can. J. Microbiol. 54:950-956.

Putievsky E, Ravid U, Duda N. 1986. The essential oil and yield components from various plant parts of Salvia fruticosa. J. Nat. Prod. 49(6):1015-1017.

Rao BRR, Kotharia SK, Rajput DK, Patel RP, Darokar MP. 2011. Chemical and biological diversity in fourteen selections of four Ocimum species. Nat. Prod. Commun. 6:1705-1710.

Rattanachaikunsopon P, Phumkhachorn P. 2010. Antimicrobial activity of basil (Ocimum basilicum) oil against salmonella enteritidis in vitro and in food. Biosci. Biotechnol. Biochem. 74:1200-1204.

Sanda K, Koba K, Nambo P, Gaset A. 1998. Chemical investigation of Ocimum species growing in Togo. Flavour Fragr. J., 13:226-232.

Sangwan NS, Farooqi AHA, Shabih F, Sangwan RS. 2001. Regulation of essential oil production in plants. Plant Growth Regul. 34:3-21. 
Sarrou E, Tsivelika N, Chatzopoulou P, Tsakalidis G, Menexes G, Mavromatis A. 2017. Conventional breeding of Greek oregano (Origanum vulgare ssp. hirtum) and development of improved cultivars for yield potential and essential oil quality. Euphytica. 213:104.

Shirazi MT, Gholami H, Kavoosi G, Rowshan V, Tafsiry A. 2014. Chemical composition, antioxidant, antimicrobial and cytotoxic activities of Tagetes minuta and Ocimum basilicum essential oils. Food Sci. Nutr. 2:146-155.

Sifola MI, Barbieri G. 2006. Growth, yield and essential oil content of three cultivars of basil grown under different levels of nitrogen in the field. Sci. Hort. 108:408-413.

Singh S, Singh M, Singh AK, Kalra A, Yadav A, Patra D.D. 2010. Enhancing productivity of Indian basil (Ocimum basilicum L.) through harvest management under rainfed conditions of subtropical north Indian plains. Ind. Crops Prod. 32:601-606.

Snoussi M, Dehmani A, Noumi E, Flamini G, Papetti A. 2016. Chemical composition and antibiofilm activity of Petroselinum crispum and Ocimum basilicum essential oils against Vibrio spp. strains. Microb. Pathog. 90:13-21.

Steel RGD, Torrie JH. 1982. Principles and procedures of statistics. A Biometrical Approach, $2^{\text {nd }}$ ed. McGraw-Hill, Inc. pp. 633.

Sun X, Shi J, Ding G. 2017. Combined effects of arbuscular mycorrhiza and drought stress on plant growth and mortality of forage sorghum. Appl. Soil Ecol. 119:384391.

Tsivelika N, Sarrou E, Gusheva K, Pankou C, Koutsos T, Chatzopoulou P, Mavromatis A. 2018. Phenotypic variation of wild Chamomile (Matricaria chamomilla L.) populations and their evaluation for medicinally important essential oil. Biochem. Syst. Ecol. 80:21-28.

Varban DL, Duda MM, Varban R. 2010. The study of the Ocimum basilicum L. specie cultivated in organic system. Pro Environ. 3:284-288.

Wannissorn B, Jarikasem S, Siriwangchai T, Thubthimthed S. 2005. Antibacterial properties of essential oils from Thai medicinal plants. Fitoterapia 76:233-236.

Wetzeil SB, Kruger H, Hammer K, Bachmann K. 2002. Investigations on morphological and molecular variability of Ocimum L. species. J. Herbs, Spices Med. Plants 9:8183-8187.

Xavier LJC, Boyetchko SM. 2002. Arbuscular mycorrhizal fungi as biostimulants and bioprotectants of crops. Appl. Mycol. Biotechnol. 2:311-340.

Yamaura T, Tanaka S, Tabata M. 1989. Light dependent formation of glandular trichomes and monoterpenes in thyme seedlings. Phytochemistry, 28:741-744.

Zheljazkov VD, Callahan A, Cantrell CL. 2008a. Yield and Oil Composition of 38 Basil (Ocimum basilicum L.) Accessions Grown in Mississippi. J. Agric. Food Chem. $56: 241-245$

Zheljazkov VD, Cantrell CL, Evans WB, Ebelhar MW, Coker C. 2008b. Yield and composition of Ocimum basilicum L. and Ocimum sanctum L. grown at four locations. HortScience. 43:737-741. 